\title{
The Wärtsilä 32GD engine for heavy gases
}

\begin{abstract}
The Wärtsilä 32GD engine is a stationary turbocharged "Gas-Diesel" engine which can operate on gas and oil fuel. The direct high-pressure gas injection is applied in this engine. The sophisticated control system of the engine allows operation on gas and oil fuel with very wide range of gas/oil fuel ratio which provides a unique flexibility of fuel usage. The Wärtsilä 32GD technology offers possibility to use good quality gas or heavier gases i.e. with high content of heavier hydrocarbons. The Wärtsilä 32GD engine development and the most important components of the Wärtsilä $32 G D$ engine are presented. The working principles, operation mode, the engine performance and emission levels are described in the paper as well. The paper includes also specification for gas and oil fuels that can be used for the engine operation. The paper is concluded with some typical applications, reference installation and experience from running the engines on challenging fuels.
\end{abstract}

Key words: heavy gases, diesel combustion, direct gas injection, high-pressure gas injection

\section{Silnik Wärtsilä 32GD przeznaczony do spalania ciężkich paliw gazowych}

\begin{abstract}
Silnik Wärtsilä 32GD jest stacjonarnym turbodoładowanym gazowym silnikiem Diesla. W tym silniku zastosowano bezpośredni wysokociśnieniowy wtrysk gazu. Zaawansowany układ kontroli silnika pozwala na stosowanie jednocześnie paliwa gazowego i olejowego w bardzo szerokim zakresie zmian proporcji miedzy tymi paliwami, co pozwala na niespotykanq swobodę doboru stosowanych paliw. Technologia silnika Wärtsilä 32GD pozwala na stosowanie zarówno lekkich gazów, takich jak gaz ziemny, jak i gazów z duża zawartościa ciężkich węglowodorów. W niniejszym artykule przedstawiono zasadę działania, możliwe tryby pracy, osiagi silnika oraz poziom emisji zanieczyszczeń. Artykut zawiera również specyfikacje możliwych do zastosowania paliw gazowych i olejowych. W podsumowaniu przedstawiono typowe zastosowania silnika Wärtsilä 32GD oraz doświadczenia z pracy silników z zastosowaniem wymagajacych paliw.
\end{abstract}

Słowa kluczowe: ciężkie paliwa gazowe, obieg Diesla, bezpośredni wtrysk gazu, wysokociśnieniowy wtrysk gazu

\section{Introduction}

The gas-diesel (GD) technology was introduced in 1987 with the Wärtsilä 32GD, the first gas engine in the Wärtsilä portfolio. This technology was mainly used in offshore applications, although it also found applications in the power plants sector. The GD technology makes it possible to run a power plant on either heavy gas or heavy oil, giving the operator fuel versatility and security against gas supply disturbances. The Wärtsilä 32GD engine uses the diesel combustion cycle in all operation modes, which offers the characteristics of a diesel engine with uncompromised output and de-rating. Recently the new Wärtsilä 32GD was introduced to the market to set new standards for high performance operation on challenging fuels, both gaseous and liquid ones.

The new Wärtsilä 32GD engine is based on the frame of the Wärtsilä 32 diesel engine with its advanced integrated lube oil and cooling water channels. Other engines which utilize the same engine block frame are: the spark-ignited Wärtsilä 34SG gas engine and the dual-fuel Wärtsilä 34DF one. The new Wärtsilä 32GD engine design principles are based on the well proven technology of the previous version but with substantial improvements coming from the new Wärtsilä 32 engine block

The Wärtsilä 32GD is a four-stroke, dual-fuel engine offering the unique feature of the gas diesel combustion principle and providing extremely high operation flexibility.

\section{Wstęp}

Technologia gazowych silników o ZS (GD) została zastosowana w 1987 r. do silnika Wärtsilä 32GD - pierwszego silnika gazowego w ofercie firmy Wärtsilä. Technologia ta była wykorzystywana głównie w zastosowaniach przybrzeżno-morskich, chociaż znalazła również zastosowanie w sektorze energetycznym. Technologia GD umożliwia pracę elektrowni albo na ciężkim paliwie gazowym, albo na ciężkim oleju, co daje swobodę operowania paliwami i zabezpieczenie w razie zakłóceń $\mathrm{w}$ dostawie paliwa gazowego. Silnik typu Wärtsilä $32 \mathrm{GD}$ we wszystkich trybach pracy wykorzystuje obieg Diesla, zapewniający charakterystykę silnika o ZS z dużą mocą na wyjściu i obniżeniem wartości znamionowych. Ostatnio wprowadzono na rynek nowy silnik Wärtsilä $32 \mathrm{GD}$ w celu ustanowienia nowych standardów wysokiej sprawności pracy silnika na wymagających paliwach, zarówno gazowych, jak i ciekłych.

Nowy silnik Wärtsilä 32GD bazuje na ramie silnika o ZS Wärtsilä 32 o wysokiej integracji kanałów oleju smarującego i wody chłodzącej. Innymi silnikami wykorzystującymi taką samą ramę bloku cylindrowego są silnik gazowy o zapłonie iskrowym Wärtsilä 34 SG oraz silnik dwupaliwowy Wärtsilä 34DF. Zasady konstrukcyjne dla nowego silnika Wärtsilä 32GD opierają się na technologii dobrze sprawdzonej we wcześniejszej wersji, lecz ze znacznymi udoskonaleniami wywodzącymi się z nowego bloku silnikowego Wärtsilä 32 . 
The engine is designed for flexible manufacturing methods and long maintenance-free operating periods. The engine is fully equipped with all essential ancillaries and a thoroughly planned interface to external systems. The Wärtsilä 32GD engine provides a perfect solution for power generation from challenging fuels at the view of natural resources shortage coming soon $[1,6,8]$.

\section{Engine technology \& design}

The engine block is one piece cast made of nodular cast iron and is of stiff and durable design to absorb internal forces. The engine block carries the under-slung crankshaft. The nodular cast iron main bearing caps are fixed from below by two hydraulically tensioned studs. The caps are fixed side-ways by hydraulically tensioned horizontal side studs. Together they provide a rigid crankshaft bearing. The inlet air receiver and the cooling water and lubricating oil channels are integrated into the engine block. The engine is provided with a wet oil sump, mounted against the engine block and sealed by an o-ring gasket. The crankshaft is forged from one piece of high tensile steel. Counterweights are fitted on the crankshaft webs. The optimum balancing results in an even and thick oil film for all bearings. The main bearings and the crankpin bearings have a steel backing and a soft running layer with excellent corrosion resistance. The connecting rod is a drop forged, totally machined type. The connecting rod is of three-piece design with a horizontal split at the crankpin bearing and a flanged connection to the rod. The oil supply for the piston cooling, gudgeoned pin bush and piston skirt lubrication takes place through a single drilling in the connecting rod.

The cylinder liner is centrifugally cast iron with special alloy elements to create wear resistance and high strength. The liner is of stiff bore cooled collar design and supported symmetrically at the top of the engine block. It is equipped with an anti-polishing ring at the top, preventing bore polishing. The piston consists of an oil cooled steel crown bolted on to a nodular cast iron skirt. The piston crown has two compression and one oil scraper rings. The piston skirt and cylinder liner are lubricated by a Wärtsilä patented pressurized lubricating system utilizing lubricating nozzles in the piston skirt. This system ensures excellent running behaviour and low lubrication oil consumption.

The cylinder head is made of nodular cast iron. The stiff design allows only four hydraulically tightened studs to fix the cylinder head on to the cylinder block. Each cylinder head has two inlet and two exhaust valves, all equipped with rotators. The exhaust valve seat rings are water cooled. The cams are integrated in the drop forged camshaft material. The bearing journals are made of separate pieces that are fitted to the camshaft sections by means of flanged connections. This design allows lateral dismantling of the camshaft sections. The camshaft bearings are located in integrated bores in the engine block casting. The camshaft is driven from the crankshaft through a fully integrated gear train.

The lubricating oil system lubricates the main moving parts of the engine and also cools the piston tops. The engine lubricating oil system includes the following equipment:
Silnik Wärtsilä 32GD jest czterosuwowym, dwupaliwowym silnikiem oferującym unikalną charakterystykę spalania gazowego silnika o ZS i zapewniającym nadzwyczaj dużą elastyczność pracy. Silnik jest zaprojektowany pod kątem elastycznych metod wytwarzania (produkcji, obróbki) i długich okresów międzynaprawczych. Jest całkowicie wyposażony w zasadnicze urządzenia pomocnicze i dokładnie zaplanowany interfejs dla systemów zewnętrznych. Silnik Wärtsilä 32GD zapewnia doskonałe rozwiązania wytwarzania energii z wymagających paliw, szczególnie w odniesieniu do nadchodzącego kryzysu surowców naturalnych $[1,6,8]$.

\section{Technologia i projekt silnika}

Blok silnika jest odlewem wykonanym z żeliwa sferoidalnego i ma sztywną oraz wytrzymałą konstrukcję dla thumienia sił wewnętrznych oraz ma podwieszany wał korbowy. Pokrywy łożysk głównych z żeliwa sferoidalnego są zamocowane od dołu za pomocą dwóch śrub dwustronnych napinanych hydraulicznie. Pokrywy zamocowane są bocznie, za pomocą poziomych bocznych śrub dwustronnych napinanych hydraulicznie. Razem tworzy to sztywne łożysko wału korbowego. Wlotowy zbiornik powietrza oraz kanały wody chłodzącej i oleju smarującego są zintegrowane $\mathrm{z}$ blokiem silnika. Silnik jest wyposażony w mokrą miskę olejową zamontowaną na bloku silnika i uszczelnioną za pomocą pierścienia uszczelniającego o przekroju okrągłym. Wał korbowy jest kuty w całości z jednego kawałka stali o dużej wytrzymałości na rozciąganie. Przeciwciężary są zamontowane na wykorbieniach wału korbowego. Optymalne wyważenie zapewnia gładką i grubą powłokę olejową dla wszystkich łożysk. Łożyska główne i czopu korbowego mają stalowy podkład i miękką warstwę nośną o doskonałej odporności na korozję. Korbowód typu odkuwki matrycowej jest obrobiony w całości. Korbowód jest konstrukcją trzyczęściową z poziomym rozszczepieniem przy łożysku korbowym i podłączeniem kołnierzowym do trzonu korbowodu. Doprowadzenie oleju chłodzącego tłok oraz oleju smarującego tuleję sworznia tłokowego i płaszcz tłoka odbywa się przez pojedynczy kanał nawiercony w korbowodzie.

Tuleja cylindrowa jest odlewem lanym odśrodkowo ze specjalnymi dodatkami stopowymi dla zapewnienia odporności na zużycie i dużej wytrzymałości. Tuleja jest sztywną konstrukcją kołnierzową chłodzoną na obwodzie i podpartą symetrycznie na górze bloku cylindrowego. Jest ona wyposażona na górze w pierścień zapobiegający zużywaniu tulei. Tłok składa się ze stalowego denka chłodzonego olejem przykręconego do płaszcza tłoka wykonanego z żeliwa sferoidalnego. Denko tłoka ma dwa pierścienie uszczelniające i jeden zgarniający olej. Płaszcz tłoka i tuleja cylindrowa są smarowane olejem za pomocą opatentowanego przez firmę Wärtsilä ciśnieniowego systemu olejenia z dyszami smarującymi w płaszczu tłoka. System ten zapewnia doskonałą pracę i niewielkie zużycie oleju.

Głowica cylindra wykonana jest z żeliwa sferoidalnego. Sztywna konstrukcja pozwala na stosowanie do zamocowania głowicy cylindra na bloku cylindrowym jedynie czterech śrub dwustronnych napinanych hydraulicznie. 
engine driven screw type main lubricating oil pump with pressure regulating valve, pre-lubricating pump with electrical motor, lubricating oil cooler, lubricating oil thermostatic valve, lubricating oil filters and crankcase ventilation pipe.

The L-configuration engine is equipped with one turbocharger and V-configuration engine is equipped with one turbocharger per each cylinder bank. The turbocharger has an axial turbine and a radial compressor and is equipped with sleeve bearings. The combustion air system includes two stage charge air cooler with fresh water cleaning device.

The engine cooling system is divided into three circuits: the 1st stage charge air cooler circuit, the 2nd stage charge air cooler circuit and the jacket cooling circuit. The cooling water system has engine driven pump for low temperature cooling circuit and engine driven pump for jacket cooling circuit.

The engine mounted exhaust gas pipes are made of cast iron, with separate sections for each cylinder. Stainless steel bellows are installed between the sections to absorb heat expansion. The pipes are fixed by brackets, but are free to move axially. The engine exhaust gas pipes are fully covered by an insulation box. The exhaust gas system includes fresh water turbine washing system.

The main engine data are shown in Tab. 1.

Table 1. The Wärtsilä 32GD engine data [6]

Tabela 1. Dane silnika Wärtsilä 32GD [6]

\begin{tabular}{|l|c|}
\hline Cylinder configuration/uktad cylindrów & $\begin{array}{c}\text { 6L 8L 9L } \\
\text { 12V 16V 18V 20V }\end{array}$ \\
\hline Cylinder bore/stroke/średnica cylindra/skok & $320 / 400 \mathrm{~mm}$ \\
\hline Speed/prędkość obrotowa & 720 or $750 \mathrm{rpm}$ \\
\hline Mean piston speed/średnia prędkość ttoka & 9.6 or $10.0 \mathrm{~m} / \mathrm{s}$ \\
\hline $\begin{array}{l}\text { Cylinder swept volume/objętość skokowa } \\
\text { cylindra }\end{array}$ & $36.3 \mathrm{dm}^{3}$ \\
\hline Compression ratio/stopień sprężania & $16: 1$ \\
\hline Engine length/dtugość silnika & 5297 to $9276 \mathrm{~mm}$ \\
\hline Engine width/szerokość silnika & 2300 to $3296 \mathrm{~mm}$ \\
\hline Engine height/wysokość silnika & 3421 to $4139 \mathrm{~mm}$ \\
\hline Engine weight/masa silnika & 30000 to $89000 \mathrm{~kg}$ \\
\hline
\end{tabular}

\section{Engine operation \& performance}

The engine is designed for operation on fuel oil or on gas and fuel oil simultaneously. Small amount of fuel oil is needed as pilot fuel in gas mode. There are three modes of the engine operation: gas-diesel mode, oil mode and fuelsharing one. In all modes the engine works according to the Diesel process. The engine is started by compressed air with a nominal pressure of 30 bar. The start is performed by direct injection of air into the cylinders through the starting air valves in the cylinder heads. The starting air valves are placed in each cylinder of L-engine and in one bank of V-engine.

In oil mode the engine operation is based on the use of normal fuel oil injection pumps and the system operates just like any diesel engine. The engine can run on light or heavy oil i.e. light fuel oil (LFO), marine diesel oil (MDO), heavy
Każda głowica cylindrowa ma dwa zawory wlotowe i dwa zawory wylotowe, każdy wyposażony w element obrotowy. Pierścienie gniazd zaworów wylotowych są chłodzone wodą. Krzywki są zintegrowane z materiałem odkuwki matrycowej wału rozrządu. Czopy łożysk wykonane z oddzielnych części są umieszczone $\mathrm{w}$ panewkach zintegrowanych $\mathrm{z}$ odlewem bloku silnikowego. Wał rozrządu napędzany jest od wału korbowego przez całkowicie zintegrowany układ przekładni.

System olejenia zapewnia smarowanie wszystkich głównych ruchomych części silnika i chłodzenie górnych partii tłoka. Silnikowy system olejenia obejmuje następujące wyposażenie: główna pompa sterująca typu śrubowego napędzana silnikiem z zaworem regulującym ciśnienie, pompa wstępnego smarowania z silnikiem elektrycznym, chłodnica oleju smarującego, zawór termostatyczny oleju smarującego, filtry oleju smarującego i przewód odpowietrzający skrzyni korbowej.

Silnik rzędowy L wyposażony jest w jedną turbosprężarkę, a silnik widlasty $\mathrm{V}$ jest wyposażony w jedną turbosprężarkę dla każdego rzędu cylindrów. Turbosprężarka ma osiową turbinę i promieniową sprężarkę oraz jest wyposażona $\mathrm{w}$ łożyska ślizgowe. System zasilania powietrzem obejmuje dwustopniową chłodnicę powietrza doładowania z urządzeniem do mycia słodką wodą.

System chłodzenia silnika dzieli się na trzy obwody: obwód chłodnicy 1. stopnia, chłodnicy 2. stopnia oraz obwód chłodzenia płaszcza cylindrów. System chłodzenia wodą ma pompę napędzaną przez silnik dla niskotemperaturowego obwodu chłodzenia i pompę dla obwodu chłodzenia płaszcza.

Zamontowane na silniku przewody wydechowe wykonane są z żeliwa z oddzielnymi sekcjami dla każdego cylindra. Pomiędzy sekcjami zamontowane są kompensatory wykonane ze stali nierdzewnej dla kompensacji rozszerzalności cieplnej. Przewody są zamocowane na wspornikach, ale mają swobodę ruchu osiowego. Przewody wydechowe są całkowicie osłonięte obudową izolacyjną. System wylotowy spalin zawiera układ wody słodkiej do mycia turbiny. Główne dane silnika przedstawiono w tab. 1.

\section{Działanie i charakterystyka silnika}

Silnik jest zaprojektowany do pracy na paliwie ciekłym lub gazowym i jednocześnie na paliwie ciekłym. Mała ilość paliwa ciekłego wymagana jest jako paliwo pilotujące przy pracy $\mathrm{w}$ trybie gazowym. Istnieją trzy tryby pracy silnika: tryb gaz-paliwo dla silnika o ZS, tryb paliwa ciekłego i tryb pracy z podziałem dawki paliwa. We wszystkich trybach silnik pracuje zgodnie z obiegiem Diesla.

Silnik uruchamia się za pomocą sprężonego powietrza o ciśnieniu nominalnym 3,0 MPa. Do rozruchu wykorzystuje się bezpośredni wtrysk paliwa do cylindrów przez zawory rozruchowe $\mathrm{w}$ głowicach cylindrów. Zawory rozruchowe umieszczone są w każdym cylindrze silnika rzędowego L i $\mathrm{w}$ jednym rzędzie cylindrów silnika widlastego $\mathrm{V}$.

W trybie pracy na paliwo ciekłe silnik pracuje z normalnymi pompami wtryskowymi paliwa i system działa tak jak w każdym silniku o ZS. Silnik może pracować albo na pali- 
fuel oil (HFO) and crude oil (CRO) however vegetable oils are also allowed. The vegetable oil used for engine operation can be high quality refined oil so-called "bio-diesel oil" (BDO) but it can be also crude vegetable oil or waste cooking oil (liquid bio fuel LBF). The oil mode is available within the full load range from zero to the rated load of the engine.

In gas-diesel mode (GD) gaseous fuel is the main source of energy and a pilot fuel oil injection of approximately $5 \%$ is used to start combustion process. The GD mode is available and gaseous fuel are injected through the same injector and between $30 \%$ and $100 \%$ of the engine load. The pilot fuel is

wie lekkim, albo na paliwie ciężkim, tj. na lekkim oleju napędowym (LFO), okrętowym paliwie napędowym (MDO), ciężkim oleju napędowym (HFO) i na nierafinowanej ropie naftowej (CRO), jednakże są również dopuszczalne oleje roślinne. Olej roślinny stosowany do zasilania silnika może być lekkim olejem napędowym o wysokim stopniu rafinacji ("bio-diesel oil" - BDO), ale może być to również ciężki olej roślinny nierafinowany lub odpadowy olej spożywczy (liquid bio fuel LBF). Tryb pracy na paliwie ciekłym jest możliwy w szerokim zakresie obciążeń, od zera do znamionowego obciążenia silnika.

Table 2. The Wärtsilä 32GD gaseous fuel requiments

Tabela 2. Wymagania dla paliwa gazowego dla silnika Wärtsilä 32GD

\begin{tabular}{|l|c|c|}
\hline Lower heating value/wartość opałowa paliwa & minimum & $30 \mathrm{MJ} / \mathrm{m}^{3}$ \\
\hline Methane contents/zawartośc metanu $\mathrm{CH}_{4}$ & minimum & $60 \%$ \\
\hline Hydrogen sulphide/siarczek wodoru $\mathrm{H}_{2} \mathrm{~S}$ & maximum & $0.05 \%$ \\
\hline Hydrogen/wodór $\mathrm{H}_{2}$ & maximum & $1 \%$ \\
\hline Carbon dioxide/dwutlenek węgla $\mathrm{CO}_{2}$ & maximum & $0.01 \%$ \\
\hline Water/woda $\mathrm{H}_{2} \mathrm{O}$ & maximum & $0.055 \%$ \\
\hline Total sulphides/dwusiarczek ogółem & maximum & $0.005 \%$ \\
\hline Chlorine + Fluorine/chlor + fluor & maximum & $10 \mu \mathrm{m}$ \\
\hline Particles or solids, size/cząstki stałe i ciała stałe & maximum & $0-50^{\circ} \mathrm{C}$ \\
\hline Gas inlet temperature/temp. gazu na wlocie & range & $350 \pm 5 \mathrm{bar}$ \\
\hline Gas pressure/ciśnienie gazu & - & 5 \\
\hline
\end{tabular}

oil fuel in injected first followed by gaseous fuel injection at 350 bar pressure. Fuel used for pilot injection can be the same as main oil fuel used for engine operation. The general requirements for gaseous fuel are presented in Tab. 2 .

The "fuel-sharing" mode (FS) is available between 35 and $100 \%$ of engine load. The fuel share set point can be adjusted on-line from WOIS (Wärtsilä Operators Interface System). The FS mode allows to burn gaseous and liquid fuel at the same time and ratio between fuels can be adjusted flexibly. The FS mode window is showed in the Fig. 1. Above and below the FS mode area there is a so-called transfer window, which mean that engine operation set point cannot be placed in this area but it will move through this area during changes of operation mode.

The Wärtsilä 32GD fuel injection system is shown in the Fig. 2. The gaseous fuel is injected through 3 nozzles located and the vertices of triangle at the injector end. Each nozzle has 3 holes, so all together 9 jets of gas are formed during gas injection. The oil fuel is injected

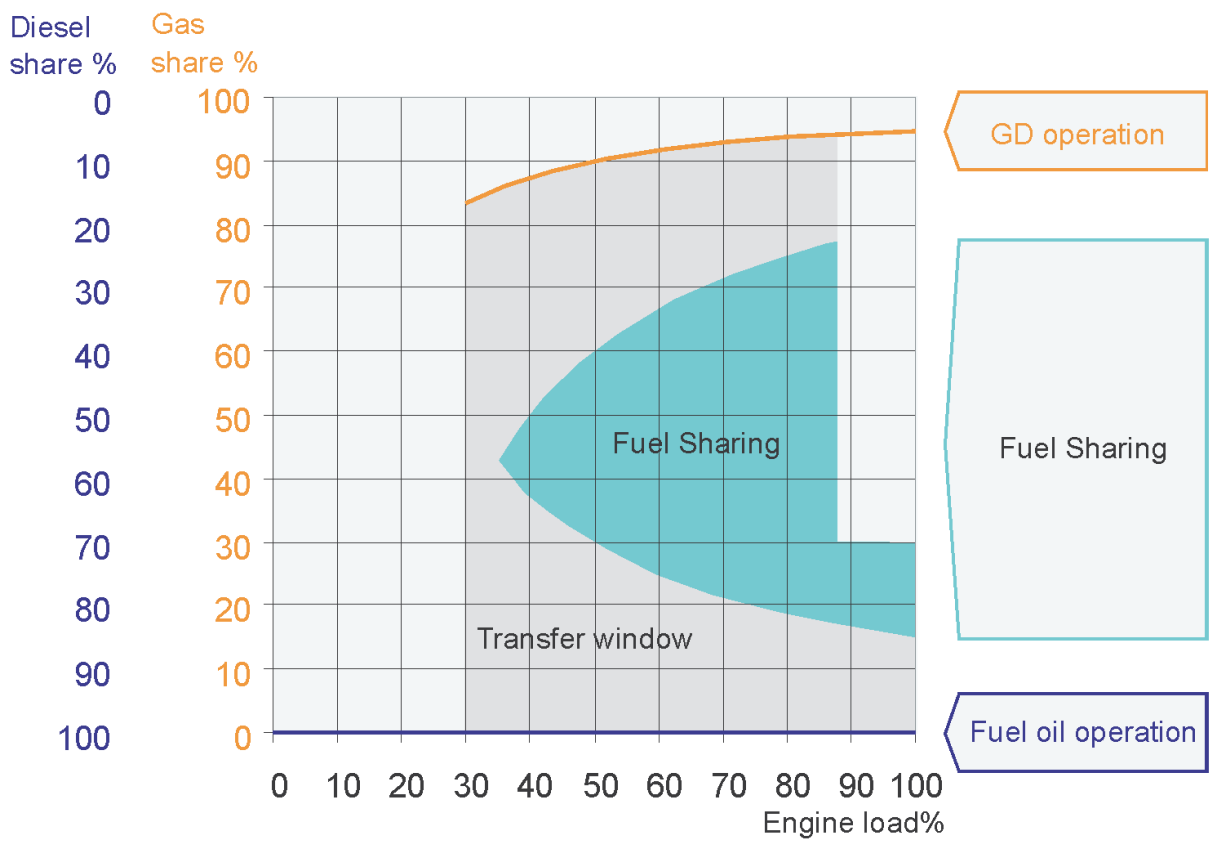

Fig. 1. The Wärtsilä 32GD operation modes [1, 8] Rys. 1. Tryby pracy silnika Wärtsilä 32GD [1,8]
W trybie pracy gaz-paliwo ciekłe (GD) paliwo gazowe jest głównym źródłem energii, a wtrysk pilotowej dawki paliwa ciekłego (w przybliżeniu 5\%) stosuje się do zapoczątkowania procesu spalania. Tryb pracy GD jest możliwy w granicach między 30 a $100 \%$ obciążenia silnika. Paliwo pilotujące i paliwo gazowe wtryskiwane są przez ten sam wtryskiwacz, a paliwo płynne wtryskiwane jest najpierw, potem następuje wtrysk paliwa gazowego przy ciśnieniu 35,0 MPa. Paliwo używane do wtrysku pilotującego może być takim samym paliwem, jak paliwo do pracy silnika. Ogólne wymagania dla paliwa gazowego są przedstawione w tab. 2.

Tryb "dzielenie paliw" (FS) jest dostępny dla obciążeń między 35 a 100\%. Punkt podziału paliwa może być nasta- 
before gas injection starts. The oil fuel nozzle located in the injector axis and has 9 holes which deliver oil fuel jets between gaseous ones. The Wärtsilä 32GD performance data is shown in Tab. 3 .

Table 3. The Wärtsilä 32GD performance data

Tabela 3. Charakterystyka silnika Wärtsilä32GD

\begin{tabular}{|l|c|}
\hline $\begin{array}{l}\text { Mean effective pressure/średnie } \\
\text { ciśnienie użyteczne }\end{array}$ & $22.9 \mathrm{bar}$ \\
\hline $\begin{array}{l}\text { Maximum firing pressure/ } \\
\text { maksymalne ciśnienie spalania }\end{array}$ & $190 \mathrm{bar}$ \\
\hline $\begin{array}{l}\text { Power per cylinder/moc z jednego } \\
\text { cylindra }\end{array}$ & $405 \mathrm{~kW}(720 \mathrm{rpm}) /$ \\
\hline $\begin{array}{l}\text { Engine efficiency/sprawnośćc } \\
\text { ogólna silnika }\end{array}$ & $420 \mathrm{~kW}(750 \mathrm{rpm})$ \\
\hline $\begin{array}{l}\text { NO } \\
\text { (at/przy } 15 \% \mathrm{O}_{2} \text { ) }\end{array}$ & $44 \%$ \\
\hline $\begin{array}{l}\text { Sound power level/poziom natę- } \\
\dot{z} \text { enia dźwięku }\end{array}$ & $1460 \mathrm{mg} / \mathrm{m}^{3}$ \\
\hline
\end{tabular}

The engine speed is measured by an optical encoder mounted at the engine free end. The encoder provides two pulsed speed signals to the high speed counter card, which enables the main processor to read the speed actual value. The generic speed control PID is used which has additional functionality for use in the fuel sharing mode. The controller can also be used independently for conventional single fuel diesel engine applications. The dedicated fuel sharing controller controls the dual actuators, the gas supply valve train sequencing, critical gas trip functions, gas inlet pressure control and high pressure sealing oil pressure set point management. For liquid fuel injection governing, the control provides a proportional actuator driver output (4-20 mA). This output signal is thereafter converted to a $0-200 \mathrm{~mA}$ signal for the actuator. The engine mounted actuator acts mechanically on the engine fuel rack and controls the amount of liquid fuel injected. The gas injection system consists of gas control valves for each cylinder and a master control unit, which controls the duration of the valve opening time for each valve individually. The control unit receives from the controller a 4-20 mA input signal as a global injection reference value, then the signal is translated to valve opening duration for the gas valves.

If gas compressor is needed (Fig. 3), it is mounted together with its all auxiliary equipment on a so-called gas compressor skid. The function of the gas compressor skid is to clean and compress the gas so that it can be used by the Wärtsilä 32GD engine. It is composed of an inlet (delivery) system, the gas compressor, electric driver, scrubbers, coolers, bypass line and all of the interconnecting piping. The number of compressor skids used at site depends on the number of engines being supplied, and the number of compression stages depends on the inlet pressure of the gas. The reciprocating compressor type is used because such compressors have a pressure range that is the broadest in the compressor family, i.e. from vacuum to 2800 bar. Typically, a multistage cross head type reciprocating compressor is used. The cylinders are either single or double acting and wiany w sposób ciągły z interfejsu WOIS (Wärtsilä Operators Interface System). Tryb FS pozwala na równoczesne spalanie paliwa gazowego i ciekłego, a proporcje pomiędzy ilościami paliwa można regulować w sposób elastyczny. Okienko dla trybu FS pokazane jest na rys. 1. Powyżej i poniżej obszaru trybu FS znajduje się tak zwane okienko przenoszenia, które oznacza, że punkt nastaw pracy silnika nie może być umieszczany w tym obszarze, ale będzie przesuwał się przez ten obszar podczas zmian trybu pracy.

System wtrysku paliwa silnika Wärtsilä 32 GD pokazany jest na rys. 2. Paliwo gazowe jest wtryskiwane przez 3 dysze umieszczone w wierzchołkach trójkąta przy końcu wtryski-

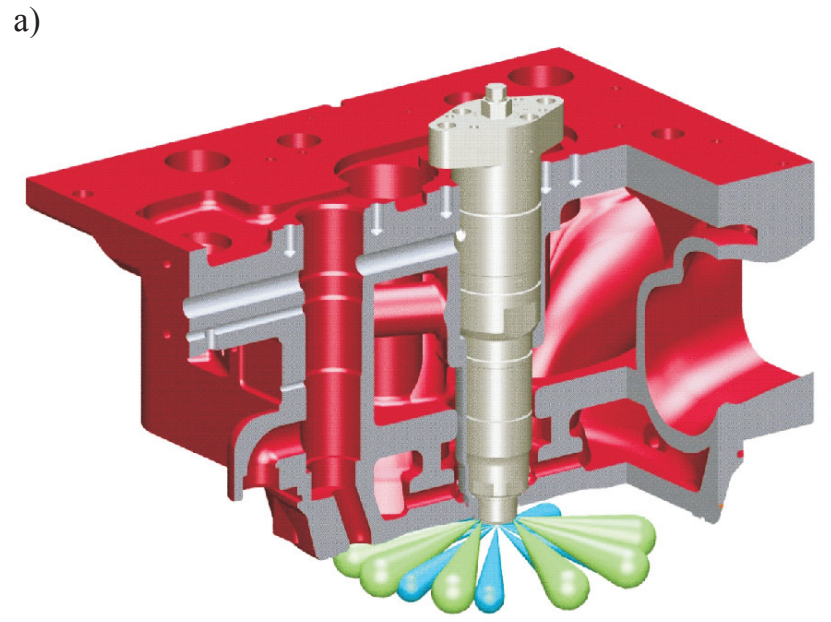

b)

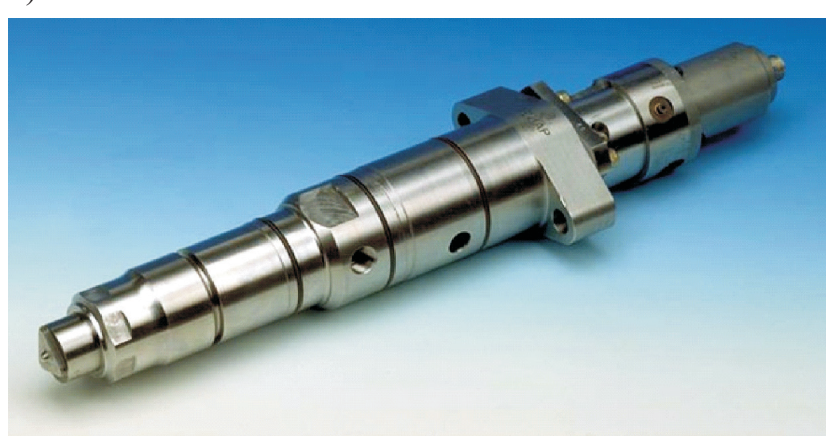

Fig. 2. The Wärtsilä 32GD fuel injection scheme (top) and fuel injector (bottom)

Rys. 2. Schemat wtrysku paliwa silnika Wärtsilä $32 G D$ (a) i wtryskiwacz paliwa (b)

wacza. Każda dysza ma 3 otwory, tak więc podczas wtrysku tworzy się razem 9 strumieni gazu. Wtrysk paliwa następuje przed rozpoczęciem wtrysku gazu. Dysza paliwa płynnego umieszczona jest w osi wtryskiwacza i ma 9 otworów, które dostarczają paliwo strumieniami pomiędzy strumieniami gazowymi. Dane dotyczące charakterystyki silnika Wärtsilä 32GD przedstawiono $w$ tab. 3.

Prędkość silnika mierzy się za pomocą optycznego znacznika kąta zamontowanego na swobodnym końcu silnika. Znacznik dostarcza dwa impulsowe sygnały prędkości do karty szybkiego licznika, która umożliwia głównemu procesorowi odczytywanie rzeczywistych wartości prędkości. Stosowana jest ogólna regulacja prędkości PID, której dodatkową funkcją jest zastosowanie paliw w 


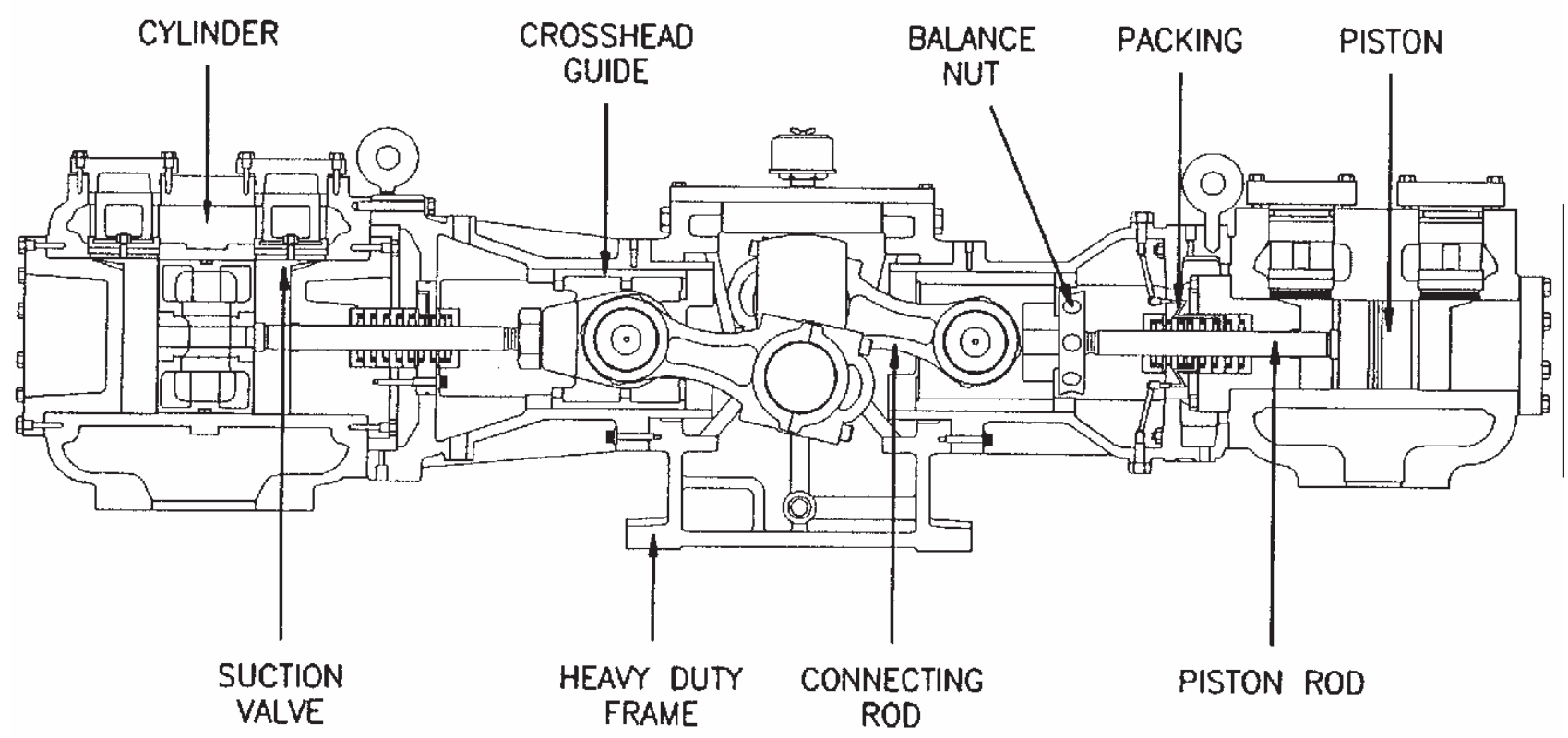

Fig. 3. The Wärtsilä 32GD gas compressor

Rys. 3. Sprężarka gazu silnika Wärtsilä 32GD

they are commonly in a horizontally opposed configuration. The compressor is water-cooled. The piston is driven by a fixed piston rod, which passes though a packing box and is connected to a crosshead. This design is used because it puts a barrier between the crankcase lubrication and the process gas.

The control and sealing oil system serves two functions: to actuate the gas needles (control oil) and to act as sealing oil between the injector housing and the gas needles (sealing oil). The oil is pumped by the high pressure unit, which is driven by an electric motor using engine lubricating oil as the pumped media.

Between the valve station and the entry point to the engine room, a seamless pipe of duplex stainless steel is used for the gas supply. From its entry point to the engine room, the high-pressure pipeline is double walled, all the way to the injection valves on the engine. The annular space between the inner and outer pipes provides a means of ventilation and leak detection. In case of a leak in the inner pipe, the gas is trapped in the space, rather than escaping into the engine room. It is the flushed out of the space, with the ventilation air, into the atmosphere.

\section{Typical applications}

In 2002 Wärtsilä was contacted by Dygoil, an Ecuadorbased company, with a specification that called for true fuel sharing capability for an oil field power supply system. Dygoil needed a power plant that could run on both associated gas and crude oil because the gas supply was not stable and gas availability was declining over time as the water cut increased. Wärtsilä took up the challenge and developed the fuel sharing system for the project. The plant with two Wärtsilä 16V32GD engines was handed over for commercial operation in March 2004 (Fig. 4). The gase- trybie dzielenia. Regulator może być również używany w konwencjonalnych zastosowaniach dla jednopaliwowego silnika o ZS. Zastosowany regulator dzielenia paliw steruje podwójnymi serwomotorami oraz sekwencjami działania układu zaworów doprowadzających gaz, krytycznymi funkcjami wyzwalania gazu, regulacją ciśnienia gazu na wlocie oraz punktem nastawy wysokiego ciśnienia oleju uszczelniającego. W przypadku regulacji wtrysku paliwa ciekłego, regulator zapewnia proporcjonalny sygnał wyjściowy z członu napędzającego serwomotor (4-20 mA). Wyjściowy sygnał jest następnie przekształcany na sygnał 0-200 mA dla serwomotoru. Zamontowany na silniku serwomotor działa mechanicznie na listwę paliwową silnika i steruje ilością wtryskiwanego paliwa ciekłego. System wtrysku paliwa składa się z zaworów sterujących gazu dla każdego cylindra i układu sterującego, który steruje długością czasu otwarcia oddzielnie dla każdego zaworu. Układ kontrolny otrzymuje z regulatora sygnał wejściowy 4-20 mA jako referencyjną wartość wtrysku, następnie sygnał jest przekształcany na czas otwarcia zaworu dla zaworów gazu.

W sytuacji, gdy wymagana jest sprężarka gazu (rys. 3), montuje się ją razem z całym wyposażeniem pomocniczym na tzw. płozie sprężarki gazu. Zadaniem płozy sprężarki gazu jest oczyszczanie i sprężanie gazu, tak by można go było zastosować do silnika Wärtsilä 32GD. Układ ten składa się z systemu wlotowego, sprężarki gazowej, elektrycznego członu napędzającego, płuczek gazowych, linii obejściowej oraz przewodów rurowych do wzajemnych połączeń. Liczba płóz sprężarkowych zależy od liczby silników, które są zasilane, a liczba stopni sprężania zależy od ciśnienia gazu na wlocie. W takich układach znajdują zastosowanie sprężarki tłokowe, ponieważ sprężarki tego typu mają najszerszy zakres ciśnień spośród dostępnych sprężarek, tj. od próżni do ciśnienia 280,0 MPa. W typowych rozwiązaniach stosowana jest 
ous fuel composition changes during plant operation are presented in Tab. 4.

Table 4. Gas samples from Dygoil and composition changes during plant operation

Tabela 4. Próbki gazu z Dygoil oraz zmiany składu paliwa gazowego podczas pracy zaktadu

\begin{tabular}{|l|c|c|}
\hline- & Sample \#1/próbka 1 & Sample \#2/próbka 2 \\
\hline $\mathrm{CH}_{4}$ & 43.74 & 35.83 \\
\hline $\mathrm{C}_{2} \mathrm{H}_{6}$ & 10.21 & 9.04 \\
\hline $\mathrm{C}_{3} \mathrm{H}_{8}$ & 12.25 & 18.21 \\
\hline $\mathrm{i}_{-} \mathrm{C}_{4} \mathrm{H}_{10}$ & 1.2 & 2.21 \\
\hline $\mathrm{n}_{-} \mathrm{C}_{4} \mathrm{H}_{10}$ & 2.32 & 5.39 \\
\hline $\mathrm{i}-\mathrm{C}_{5} \mathrm{H}_{12}$ & 0 & 0 \\
\hline $\mathrm{n}-\mathrm{C}_{5} \mathrm{H}_{12}$ & 0 & 1.91 \\
\hline $\mathrm{n}-\mathrm{C}_{6} \mathrm{H}_{14}$ & 0 & 4.66 \\
\hline $\mathrm{CO}_{2}$ & 27.49 & 19.9 \\
\hline $\mathrm{N}_{2}$ & 2.79 & 2.85 \\
\hline LHV & $37 \mathrm{MJ} / \mathrm{m}^{3}$ & $55 \mathrm{MJ} / \mathrm{m}^{3}$ \\
\hline Density/gęstość & $1.34 \mathrm{~kg} / \mathrm{m}^{3}$ & $1.59 \mathrm{~kg} / \mathrm{m}^{3}$ \\
\hline
\end{tabular}

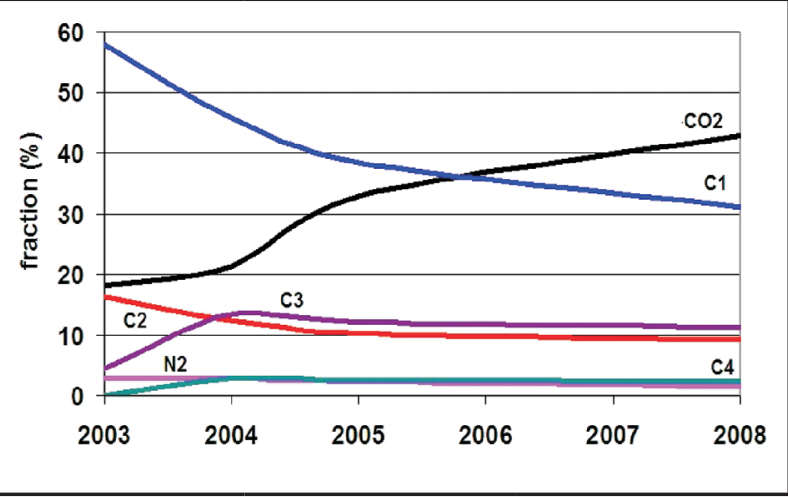

Wärtsilä offers a solution for plant operators which enable them to switch from using heavy oil to more environmentally sound energy sources. In the 90s R\&D department together with Wärtsilä Service department developed concept of converting diesel engines into gas-diesel ones. This conversion is very easy and cost-effective since the Wärtsilä 32 and the Wärtsilä 32GD are based on the same frame, have the same combustion process, compression ratio, valve timing and even cylinder bore is the same. This conversion is also the most flexible solution since the Wärtsilä $32 \mathrm{GD}$ is not sensitive so much to gas quality. The only drawback is the high gas pressure required which sometimes may lead to the need of gas compressor installation at site. The changes on the engine required for such conversion are very simple: only fuel injectors and fuel system need to be upgraded. Many oil companies pay penalties for burning waste heavy gas at oilfield in the flare. If they convert diesel to gas-diesel engine, they benefit from more environmental approach and using cheaper fuel for power generation. They also reduce environmental impact of power generation. Norwegian Statoil decided to convert two of the platform's eight Wärtsilä 12V32 diesel engines from MDO to associated gas. In close cooperation with Statoil, the Wärtsilä team carried wodzikowa sprężarka tłokowa. Cylindry są typu pojedynczego lub dwustronnego działania i zazwyczaj występują w konfiguracji poziomej przeciwbieżnej. Sprężarka chłodzona jest wodą. Tłok jest napędzany przez umocowany trzon tłoka, który przechodzi przez komorę dławikową i podłączony jest do wodzika. Stosuje się takie rozwiązanie konstrukcyjne, ponieważ stawia ono barierę pomiędzy smarowaniem skrzyni korbowej i gazem technologicznym.

System sterowania i uszczelniania olejowego pełni dwie funkcje: uruchamia iglice gazu (sterowanie oleju) i działa jako uszczelnienie olejowe pomiędzy obudową wtryskiwacza i iglicami gazu. Olej pompowany jest przez układ wysokociśnieniowy, który jest napędzany przez silnik elektryczny wykorzystujący olej smarujący silnik.

Pomiędzy stanowiskiem zaworów i punktem wejścia do maszynowni do doprowadzania gazu stosowana jest rura bezszwowa $\mathrm{z}$ dupleksowej stali nierdzewnej. Od punktu wejścia do maszynowni rurociąg ma podwójne ścianki na całej długości, aż do zaworów wtryskowych na silniku. Pierścieniowa przestrzeń pomiędzy zewnętrznymi i wewnętrznymi przewodami rurowymi umożliwia wentylację i wykrycie nieszczelności. W przypadku nieszczelności w wewnętrznym przewodzie rurowym gaz raczej pozostaje uwięziony w przestrzeni, a nie ucieka do maszynowni. Jest on wypłukiwany z przestrzeni do atmosfery przez układ wentylacji.

\section{Typowe zastosowania silnika}

W roku 2002 firma Dygoil z Ekwadoru nawiązała kontakt $\mathrm{z}$ firmą Wärtsilä, przedstawiając specyfikację, która w rzeczywistości wymagała zapewnienia zdolności do dzielenia paliwa w systemie zasilania dla pola naftowego. Firma Dygoil potrzebowała elektrowni, która mogłaby pracować na stosowanych obok siebie paliwach, tj. zarówno na paliwie gazowym, jak i nierafinowej ropie naftowej, ponieważ dostawy gazu nie były stabilne, a dostępność gazu malała w miarę jak zawartość wody w objętości ogółem produkowanych cieczy wzrastała. Wärtsilä podjęła wyzwanie i opracowała wymagany system dla projektu. Zakład z dwoma silnikami Wärtsilä 16V32GD (rys. 4) został oddany do użytku w marcu 2004 r. Zmiany składu paliwa gazowego podczas pracy zakładu przedstawiono $\mathrm{w}$ tab. 4.

Wärtsilä oferuje użytkownikom zakładu rozwiązanie, które umożliwia przechodzenie z ciężkiego oleju napędowego na źródła energii bardziej przyjazne dla środowiska. W latach dziewięćdziesiątych XX w. dział badawczo-rozwojowy i dział obsługi klienta firmy Wärtsilä opracowały sposób przekształcania silników o ZS na silniki gazowo-samoczynne. Taka konwersja silnika jest bardzo łatwa do wykonania i oszczędna w kosztach, ponieważ silniki Wärtsilä 32 i Wärtsilä 32GD opierają się na takiej samej ramie, mają taki sam proces spalania i stopień sprężania, takie samo ustawienie rozrządu, a nawet taką samą średnicę cylindra. Ta konwersja jest również najbardziej elastycznym rozwiązaniem, ponieważ silnik Wärtsilä 32GD nie jest tak bardzo wrażliwy na jakość gazu. Jedyną wadę stanowi wysokie ciśnienie gazu, które niekiedy wymaga zainstalowania sprężarki gazu. Zmiany silnika wymagane przy takiej konwersji są bardzo proste: 
out the conversion as well as a total upgrade to the latest technology. A complete rebuilding of two other engines that had been in operation for ten years was done as well. The entire project was carried out in just three months on board Veslefrikk platform in the North Sea, without disturbing oil production [4].
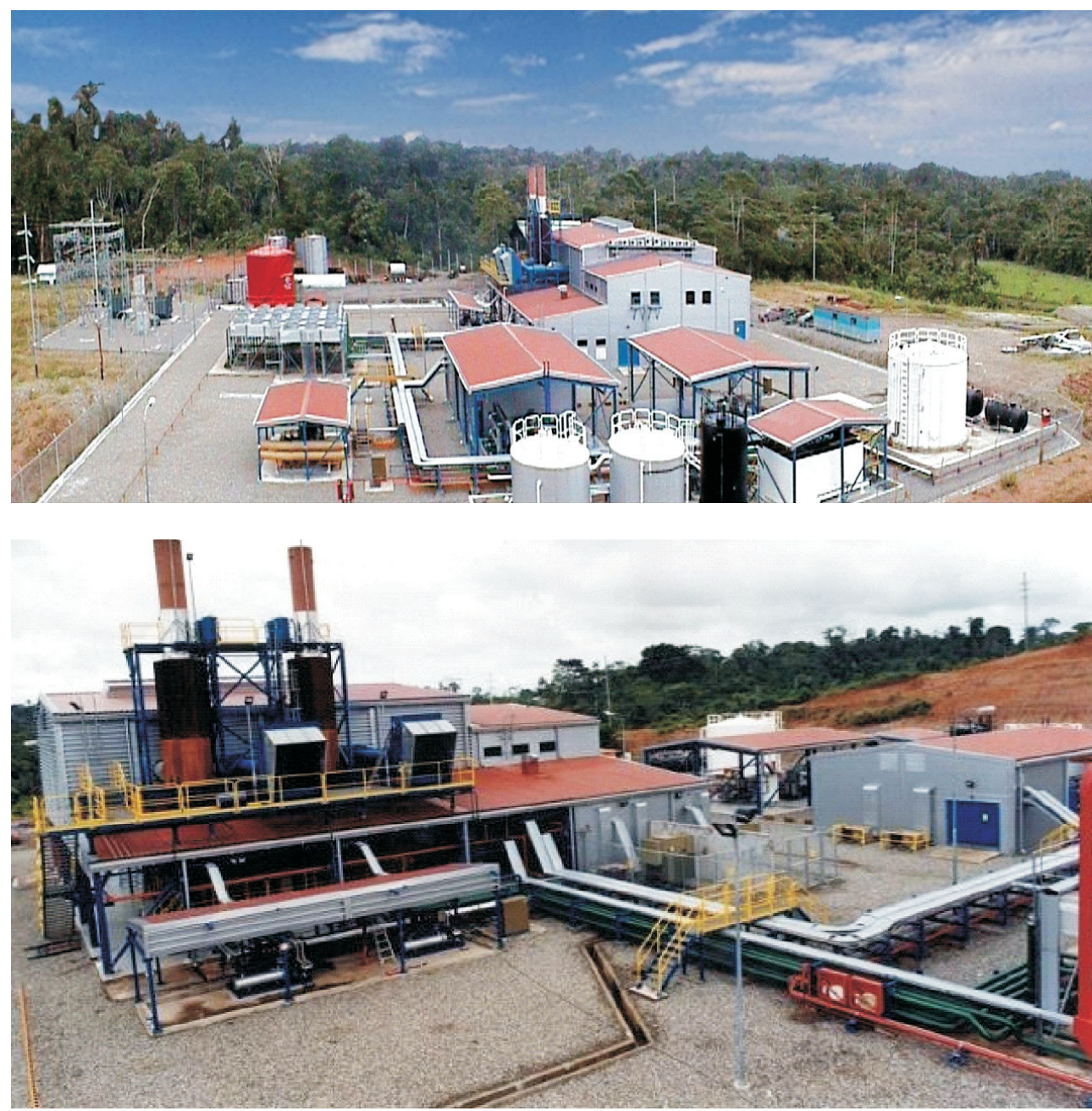

Fig. 4. Dygoil power plant powered by two Wärtsilä 16V32GD gas-diesel engines Rys. 4. Elektrownia Dygoil zasilana przez dwa gzowe silniki o ZS Wärtsilä 16V32GD

jedynie wtryskiwacze paliwa i system paliwowy wymagają udoskonalenia. Wiele kompanii olejowych płaci kary za spalanie zużytego ciężkiego gazu na polach naftowych w płomieniu otwartym. Jeżeli dokonują oni przekształcenia silnika o ZS na silnik dwupaliwowy, to odnoszą korzyści ze względu na bycie przyjaznym dla środowiska oraz na stosowanie tańszego paliwa do wytwarzania mocy. Osłabiają również negatywny wpływ wytwarzania mocy na środowisko naturalne. Firma Norwegian Statoil postanowiła przekształcić dwa spośród ośmiu silników o ZS Wärtsilä 12V32 zamontowanych na platformie $\mathrm{z}$ pracy na paliwie MDO na towarzyszący mu gaz. Zespół firmy Wärtsilä w ścisłej współpracy z firmą Statoil dokonał takiej konwersji z całkowitym dostosowaniem do najnowszej technologii. Przeprowadzona została również kompletna przebudowa dwóch innych silników, które znajdowały się w eksploatacji od dziesięciu lat. Całość została wykonana w ciągu zaledwie trzech miesięcy na platformie Veslefrikk na Morzu Północnym bez zakłócania procesu produkcji oleju [4].

Silnik Wärtsilä 32GD jest bardzo przydatny nie tylko wtedy, gdy chodzi o jakość paliwa. Jest on bardzo dobrym rozwiązaniem również dla przepompowni. Miasto algierskie

The Wärtsilä 32GD is very suitable not only when fuel quality is challenging. The engine is very good solution also for pumping stations. An Algerian town Tamanrasset located deep in the Sahara in the Ahaggar Mountains at an altitude of 1320 metres, almost a thousand metres higher than the source of water at In Salah. The contract requires Wärtsilä to supply 18 engine-driven pump sets and ancillary equipment to six pumping stations along the 740 kilometre of water pipeline route. The site conditions are quite extreme at Africa's largest desert with very high daytime temperatures and bitter cold at night. The two pipelines, each of them $800 \mathrm{~mm}$ in diameter, will eventually be able to supply 100 thousands cubic meters of water each day. Water flow is about 4000 $\mathrm{m}^{3}$ (four million litres) per hour. Each pumping station will have three Wärtsilä 6L32GD engines powering centrifugal
Tamanrasset jest usytuowane w głębi Sahary w górach Ahaggar na wysokości $1320 \mathrm{~m}$, prawie tysiąc metrów wyżej niż źródło wody w In Salah. Firma Wärtsilä zawarła kontrakt na dostarczenie tam 18 zespołów pomp napędzanych silnikiem oraz wyposażenie pomocnicze dla sześciu przepompowni wzdłuż $740 \mathrm{~km}$ odcinka rurociągu. Panują tam ekstremalne warunki, charakterystyczne dla największej pustyni w Afryce, $\mathrm{z}$ bardzo wysokimi temperaturami w ciągu dnia i dotkliwym zimnem w nocy. Dwa rurociągi, każdy o średnicy $800 \mathrm{~mm}$, będą w stanie dostarczyć $100000 \mathrm{~m}^{3}$ wody każdego dnia. Przepływ wody wynosi około $4000 \mathrm{~m}^{3} / \mathrm{h}$. Każda przepompownia będzie miała trzy silniki Wärtsilä 6L32GD zasilające pompy odśrodkowe przez przekładnię zwiększającą prędkość. Silniki Wärtsilä 32GD wybrano tak, aby zapewnić: możliwość pracy zarówno na paliwie 
pumps via a speed increasing gearbox. The Wärtsilä 32GD engines were specified for two main reasons - their ability to use both diesel and gas as fuel and their variable speed capability. For the first few years, the engines will run on diesel fuel oil [5].

\section{Summary}

The Wärtsilä 32GD engine is an upgraded successor of the first Wärtsilä gas engine developed in the 80's. The engine technology combines well proven solutions with the most modern design.

The Wärtsilä 32GD engine is an excellent solution for applications when gaseous fuel supply or composition is expected to vary significantly. It is also very good solution for heavy gases which are usually treated as waste product.

The engine is very useful as a drive for compressors or pumps along the pipelines. It has proven its capability to work in extreme conditions, i.e. at high altitude like in Equator or at very hot conditions like in Algeria. It is very reliable power source at oilfields either on land or sea.

The Wärtsilä 32GD engine offers high efficiency and operation flexibility by providing unique gas-diesel combustion with fuel-sharing mode as an option. Customers have possibility to convert existing Wärtsilä diesel engines to the Wärtsilä 32GD if it's needed and improve plant feasibility or flexibility together with reduction of environmental impact of site activity.

Artykut recenzowany dla silnika o ZS, jak i gazowym oraz możliwość pracy przy zmiennych prędkościach. Przez kilka pierwszych lat silniki będą pracować na paliwie do zasiania silnika o ZS [5].

\section{Podsumowanie}

Silnik Wärtsilä 32GD jest udoskonalonym następcą pierwszego silnika gazowego firmy Wärtsilä, opracowanego w latach 80. XX w. Technologia silnika łączy dobrze sprawdzone rozwiązania wcześniejsze ze współczesnymi rozwiązaniami.

Silnik Wärtsilä 32GD jest doskonały do zastosowań w sytuacji, gdy oczekuje się, że dostawy paliwa gazowego lub jego skład będą zmieniać się znacząco. Jest on również dobrym rozwiązaniem w przypadku stosowania ciężkich gazów, które zwykle są traktowane jako odpady produkcyjne.

Jest bardzo przydatny do napędu sprężarek lub pomp rozmieszczonych wzdłuż rurociągów. Silnik wykazał zdolność do pracy w warunkach ekstremalnych, tj. na dużej wysokości, jak w Ekwadorze, lub przy wysokich temperaturach, jak w Algierii. Jest bardzo niezawodnym źródłem mocy dla pól naftowych, zarówno na lądzie, jak i na morzu.

Silnik Wärtsilä 32GD ma dużą efektywność i elastyczność pracy przez wykorzystywanie unikalnego procesu spalania gazowo-samoczynnego z trybem pracy dla dzielonego paliwa w opcji. Klienci firmy mają możliwość konwersji istniejących silników o ZS Wärtsilä na silnik Wärtsilä 32GD, o ile jest takie zapotrzebowanie, oraz możliwość elastycznej pracy połączonej z ograniczeniem niekorzystnego wpływu pracującego urządzenia na środowisko naturalne.

\section{Nomenclature/Oznaczenia}

BDO Bio-Diesel Oil/lekki olej roślinny (rafinowany)

CRO Crude Oil/nierafinowana ropa naftowa

HFO Heavy Fuel Oil/ciężki olej napędowy

LBF Liquid Bio Fuel/ciężki olej roślinny (nierafinowany)

LFO Light Fuel Oil/lekki olej napędowy

LHV Lower Heating Value/wartość opałowa paliwa
MDO Marine Diesel Oil/okrętowy olej napędowy

PID Proportional-integral-derivative controller/regulator proporcjonalno-całkujaco-różniczkujący

PLC Programmable Logic Controller/programowalny sterownik logiczny

WOIS Wärtsilä Operators Interface System/interfejs systemu operacyjnego Wärtsilä

\section{Bibliography/Literatura}

[1] Gas Power Plants, Wärtsilä Corporation brochure, 2007.

[2] Klimstra J.: The road to obtaining the ultimate performance of gas engines - opportunities and challenges, 5th Dessau Gas Engine Conference proceedings, 2007.

[3] Pakarinen R.: Smooth sailing in the desert, Twentyfour7 Wärtsilä Stakeholder Magazine 02.2008, pp. 63-64.

[4] Pagni J.: Gas conversions get the green light, Twentyfour7 Wärtsilä Stakeholder Magazine 02.2008, pp. 60-62.

Mr. Christer Järf, BEng. - Application Manager in Gas Plants at Wärtsilä Finland.

Inż. Christer Järf - application manager $w$ dziale elektrowni gazowych Wärtsilä Finland.

e-mail: christer.jarf@wartsila.com
[5] Pagni J.: Water brings life to the desert, Twentyfour7 Wärtsilä Stakeholder Magazine 04.2008, pp. 62-63.

[6] Power Plants Product Programme, Wärtsilä Corporation brochure, 2nd edition, 2008.

[7] Sutkowski M.: The combustion systems in the high-power stationary internal combustion engines, XX International Symposium on Combustion Process proceedings, 2007.

[8] Wärtsilä 32GD - gas-diesel for oil field power production, Wärtsilä Corporation brochure, 2007.

Mr. Marek Sutkowski, PhD, MSc, Eng. - Application Manager in Gas Plants at Wärtsilä Finland.

Dr inż. Marek Sutkowski - application manager $w$ dziale elektrowni gazowych Wärtsilä Finland.

e-mail: marek.sutkowski@wartsila.com 